Article

\title{
Unreal Homes: Belonging and Becoming in Indian Women Narratives
}

\author{
Sofia Cavalcanti \\ Department of Interpretation and Translation (Forlì Campus), University of Bologna, Corso della Repubblica, \\ 136, 47121 Forlì (FC), Italy; sofia.cavalcanti2@unibo.it; Tel.: +39-328-761-8562
}

Received: 15 November 2018; Accepted: 14 December 2018; Published: 17 December 2018

\begin{abstract}
In an epoch which has to do fundamentally with space, the concept of home has entered the epistemic scene, both as a commodity and a discursive formation. Contemporary Indian women writers, who are a major facet of present Anglophone literature, have often chosen the domestic sphere as the structural framework of their stories. However, despite the traditional idea of home as a static physical site where women's lives unfold, a more complex and fluid concept emerges from their narratives. After discussing conflicting definitions of home both as a site of belonging and becoming, I will provide a comparative analysis of the short story Mrs. Sen's by Jhumpa Lahiri and the novel Ladies' Coupé by Anita Nair. By looking at the transitional spaces inhabited by the women protagonists - respectively, the diasporic space in the U.S. and a train car in India-I will show how home is a psychic-inhabited place taking shape in memory, imagination, and desire. In conclusion, home is an unreal site at the core of women's subjectivities, transcending the physicality of the homeland or the household and assuming a metonymic significance. Its inward or outward-moving force gives birth to "homeworlds" made of liminal paths where new possibilities of identity construction are produced.
\end{abstract}

Keywords: home; gendered spaces; Indian women narratives; women's identity; domestic microcosm; transitional spaces; Anglophone Indian literature; Jhumpa Lahiri; Anita Nair

\section{Introduction}

In the present era, characterized by globalization and ceaseless movements of people across borders, the notion of home has occupied a central position in the epistemic discourses, both as a living territory and as an integral part of people's psychical life. As Foucault had anticipated, our epoch "will perhaps be above all the epoch of space .... The anxiety of our era has to do fundamentally with space, no doubt a great deal more than with time" (Foucault 1986, p. 23). Since the 1980s, a considerable increase in migrations across the globe has been registered, as Avtar Brah has pointed out (Brah 2005, pp. 194-95), and those dispersions of people embody the very idea of center; that is, a home from which the movement occurs. As a combination of architectural settings and social practices, home is a problematic concept both in terms of commodity-including the complex spatial dynamics it encompasses-and as discursive formation linked to the "homing desire" of individuals (ibid., p. 32); i.e., their need to feel at home. From the perspective of Brown's "Thing Theory" (Brown 2001), the house is an objectification of the thingness of the home-where "thingness" refers to an array of human sensibilities such as memory, meaning, emotion, etc. Both aspects feed into the politics of home and identity formation, but the discourses around such a complex notion have demonstrated a universalizing tendency to tackle it from an unmarked and normalizing male perspective. However, the growing feminization of migration, on the one hand, and the inextricable bond between women and the domestic sphere in most cultures, on the other, require a gender perspective when discussing the idea of home and the social and cultural dynamics surrounding it. As George underlines in her 
book The Politics of Home (George 1999, p. 19), the issue of home and the private sphere is usually embedded in discourses on women. Indeed, while for men home is a refuge of cultural security as well as a site for escape and respite, for women it often connotes the private sphere of patriarchal hierarchy and oppression. The same geographical and physical place, then, comes to articulate different histories, so that home can be simultaneously a place of safety and terror, a conflicting site of belonging and becoming, both limiting and liberating.

Such a duality is particularly evident in the literature produced by contemporary Anglophone Indian women writers, who point out how Indianness and womanhood are not placeless, but rather formed and informed by place. Home, both as a geographical and a metaphorical site, is crucial in the construction of the Indian woman. Hence, the domestic sphere is foregrounded not only as the primary arena for social life, but also as a patriarchally-designated space which women have internalized to such an extent that it shapes their individual identities. Dasgupta notes how, in the Indian public debate and common understanding, women are equated with home and, within this private sphere, they have the symbolic function of preserving tradition, the desi culture, and the national values (Dasgupta 2007, p. 77). As Nandana Dutta has claimed in her essay Indian Women's Fiction and the Fascination of the Everyday, everything involving the house, the small, and the material has become the structural framework of their stories, holding the narrative together (Dutta 2013, p. 147). The micro-activities performed by the women characters in their kitchens, bedrooms, and gardens are actually micro-politics at work, and through the representation of the daily life, inside the spaces traditionally inhabited by women, their sense of self is recovered and new forms of empowerment can be achieved. Lisa Lau has also observed that South Asian women authors provide detailed descriptions of the domestic spaces in which the women's lives unfold and their identity negotiations take place (Lau 2006, p. 1098). The physical structure of their homes usually reflects their status in the social system, as the domestic sphere is the preeminent site where women can contest patriarchy and acquire a positionality in the family. However, as George also points out (George 1999, p. 20), paralleling the style of a woman's dwelling with the development of her psyche is a problematic association which suggests a static, basic, and even primitive way of interpreting women's inner world. Moreover, despite the idea of home moving along different axes, in fiction "it is usually represented as fixed, rooted, stable - the very antithesis of travel" (ibid., p. 2). In contrast to this tendency, in recent writings by Indian women authors, a new idea has been added to the notion of home as a static physical site where women defend, contest, and search for their identity. What emerges from those narratives is a more fluid concept of home that transcends the physical boundaries, thereby becoming a subjectively experienced place in which multiple subject positions are possible. James Clifford, in his essay Traveling Cultures, has stated that it is necessary to reconceive dwelling as "no longer simply the ground from which traveling departs, and to which it returns" (Clifford 1992, p. 115). This perspective suggests reading not only more than the domestic into representations of the home, but also imagining location as different from a single geographical place. If we consider the literature of the diaspora, for instance, the idea of home acquires blurred characteristics in the tension between here and there, present and past, local and global. Borders become the very location in which identity formation takes place, opening up multiple semiotic spaces in which individuals can develop a sense of self through encounters and exchanges. Hence, in the postmodern world, home cannot be reduced to just a thing, but becomes an emotional determinant in the construction of identity. As our boundaries expand, instability enters the idea of home, challenging its assumed notion of purity. The ideal homogeneity of the domestic sphere gives way to ambiguity and fluidity to such an extent that home ceases to be a real place associated with roots. It becomes instead increasingly connected with the idea of routes, with a specific emphasis on travel and multiple locations. As Lal and Kumar claim in their introduction to the volume they edited, Interpreting Homes in South Asian Literature, it is necessary to stretch the conventional boundaries of home and "comprehend the new shapes and contours of human identity locating itself in new mental and physical homes" (Lal and Kumar 2007, introduction). The aim of this paper is, therefore, to focus greater attention not much on what home is as on where home is and how 
it is represented in women's narrations. This perspective will shed a new light on contemporary Indian women writers' attempt to re-write home through the deconstruction of the traditional binarism of the private and public sphere as well as the re-orientation of geographical, psychological and material connotations of the domestic space.

In the following sections, two contemporary Indian English literary works, namely Jhumpa Lahiri's short story Mrs. Sen's (Lahiri 1999) and Anita Nair's novel Ladies' Coupé (Nair 2001), are examined, concentrating on the transitional space inhabited by the women protagonists. On the one hand, I will read Mrs. Sen's experience of "homelessness" by examining the spiritual and material "luggage" she has carried over to the U.S. in order to understand whether it impedes or facilitates belonging. On the other hand, I will investigate Nair's protagonist's reterritorialization via narration to show how women's struggle and creativity can be allowed by displacement. The aim is to show that both narratives, set respectively in the diasporic space of the U.S. and in a train car in India, challenge a stable idea of home, which is instead depicted as a mutable psychical-inhabited place, taking shape in memory, imagination, and desire. As a gendered spatiality at the core of women's subjectivities, home progressively loses its phenomenological characteristics, thereby assuming a metonymic significance, which will be investigated in the two different contexts.

After discussing the varied, often conflicting meanings of home, an analysis follows of the liminal space occupied by the women protagonists of the narratives examined in this work, as well as the critical transition they experience in that grey zone.

\section{The Blurred Borders of Home}

As a central point of interaction for many different disciplines, "home" has been given multiple definitions shifting from the private to the public sphere. On the one hand, as Ahmed has pointed out, home can be where one usually lives, where one's family lives, or one's native country (Ahmed 1999, p. 340). This idea refers to the very physical and geographical aspect of a place where one's roots lie. George also underlines that one of the primary connotations of home is of the "'private' space from which the individual travels into the larger arenas of life and to which he or she returns at the end of the day" (George 1999, p. 11). The "ritual of return" is also at the center of Benjamin's viewpoint on home, which he defines as a descriptive term used in social, scientific, humanistic, and architectural literatures to describe a place of regular residency or origin (Benjamin 1995, pp. 295-96). On the other hand, George writes, home can be an imagined location "more readily fixed in a mental landscape than in actual geography" (George 1999, p. 11). David Morley also focuses on a more figurative meaning of home, arguing that it is "not necessarily (or only) a physical place", but rather a rhetorical construction (Morley 2000, p. 17). It is, therefore, a site of both belonging and becoming where various discursive formations converge. On the changing nature of home, bell hooks claims that "[h]ome is no longer just one place. It is locations. Home is that place which enables and promotes varied and everchanging perspectives, a place where one discovers new ways of seeing reality, frontiers of difference (Hooks 1991, p. 148). Heidi Armbruster confirms the fluidity of this concept by claiming that "[home] may involve an actual place of lived experience and a metaphorical space of personal attachment and identification" (Armbruster 2002, p. 120). In the same vein, Avtar Brah develops a double notion of home as "the lived experience of a locality", in which everyday life takes place, but also as a "mythic place of desire" (Brah 2005, pp. 209-10), thus subverting its stability and situating it at the level of psychical life. This critical shift from physical location to psychical interpretation is also represented in Chandra Talpade Mohanty's formulation, in which "being at home" refers to "the familiar, safe, protected boundaries", whereas "not being home" is a matter of realizing that home was "an illusion of coherence" (Mohanty and Martin 1986). Emotion, illusion, and desire enter the definition of home, which consequently becomes a timeless and spaceless category inhabited by the unconscious. The humanist geographer Gillian Rose, for instance, claims that it is impossible to make sense of a place "full of human significance" (Rose 1993, p. 41) unless academics listen to the interpretations of those who lived in it. Hence, home is neither natural nor neutral, but socially 
constructed and deeply linked to human experience, as Pallasmaa also notes: "As well as being a symbol of protection and order, home can, in negative life situations, become a concretization of human misery: of loneliness, rejection, exploitation and violence" (Pallasmaa 1995, p. 134). The difficulty in framing home precisely means that it is defined more by what is outside it than within. In George's terms, "[the] distance from the very location that one strives to define is ... intrinsic to the definition that is reached" (George 1999, p. 2). As a result, one tends to look for a meaning based on separation, and reconciliation is only possible through narrative and memory.

Commenting on the condition of being away from home, Sara Ahmed claims that home is a far too purified space of belonging in which "the subject is too comfortable to question the limits or borders of her or his experience" (Ahmed 1999, p. 339). Consequently, to leave home is to suspend the boundaries in which identities are trapped and represents a challenge to both physical and psychical confinement. Ahmed argues that home is where the self is going and, therefore, internalized. In her view, then, home does not coincide with a stasis of being or a model of familiarity, but with a narrative journey during which the self experiences a spatial reconfiguration. Another dimension, according to Ahmed's argument, adds to the notion of home; that is, affect, or, in other words, the way in which one feels or fails to feel. As a result, the boundary between the self and home, inner and outer world, becomes permeable to such an extent that "being-at-home suggests that space and subject leak into each other" (ibid., p. 341). Adopting Ahmed's perspective for reading the works under consideration means observing that all the oppositions which have traditionally characterized the idea of home are inevitably deconstructed. Indeed, by inhabiting a diasporic territory, on the one hand, and boarding a train, on the other, both women transcend the binary division between private and public, thereby entering a third-dimension free form borders, limits, or barriers. In the next section, the advantages of such a transitional space will be discussed in terms of identity construction from a gender perspective, with a specific reference to Lahiri and Nair's works of fiction.

\section{Transitional Spaces: The Diasporic Land and the Train Coupé}

The idea of the transitional space as an obscure zone and unformed model of spatiality suggested by Miles in his essay After the Public Realm: Spaces of Representation, Transition and Plurality (Miles 2000) should not be associated with a negative image of instability or confusion. On the contrary, it is in its vagueness that all its liberating potential lies. Its transitory nature allows for a suspension of identity as well as a revision of what is meant by home. Consequently, the dwellers of that locus find the conditions "to produce their own mutable spaces" (ibid., p. 256) and create a new personal notion of home. An interesting aspect to notice about the women protagonists of the works examined is that they both inhabit the realm of the "unhomely"; that is, a condition of displacement causing the borders between home and world to become confused. As Bhabha explains, "the private and the public become part of each other, forcing upon us a vision that is as divided as it is disorienting" (Bhabha 1992, p. 141). Mrs. Sen and Akhila share the same feeling of estrangement from that which they considered as home. The place that used to be familiar has become a strange land, causing them both to experience "homelessness" in the psychical, if not the physical space. For instance, while sitting in her apartment in the U.S., Mrs. Sen travels with her mind to her lost India, which represents an anchor in her confused present: "She ... looked around the room, as if she noticed in the lampshades, in the teapot, in the shadows frozen on the carpet, something the rest of them could not. 'Everything is there.'" (Lahiri 1999, p. 113). A similar feeling of estrangement is aroused by Akhila's natal home, which annihilated her to such an extent that she feels a desperate need to escape: "She would go. She had to, or she would go mad confined within the walls of the house and the life she was expected to live" (Nair 2001, p. 4). As Rosenstein underlines in her essay Not a Home: Hindi Women Poets Narrating 'Home' (Rosenstein 2007), for Indian women, the homely frequently slides into unhomely, the potential cosiness of the familiar objects into dread. The two examples above not only show that home might become a place of suffocating domesticity "packed with objects of patriarchal oppression" (ibid., p. 157), but they also suggest that a woman has to lose home- to become homeless-to acquire 
identity. Hence, either as a site of memory or as an actual place, home is a fundamental presence in women's lives and activates the processes of critical transition depicted in both stories.

As will be shown in greater detail in the next two sections, the women progressively enter what Homi Bhabha calls the "Third Space" (Bhabha 1994, p. 37), characterized by hybridity and a great potential for openness and creativity. However, Mrs. Sen and Akhila act and react differently to the tensions developed within that interstitial place, which releases both a strangling and a nurturing force.

\subsection{The Diasporic Space in "Mrs. Sen's"}

Mrs. Sen's is the sixth short story of Lahiri's collection The Interpreter of Maladies (Lahiri 1999), which was awarded the 2000 Pulitzer Prize for fiction. It occupies a unique position in her corpus of writing as it is the only piece about a first-generation female immigrant, based on her mother's personal experience of babysitting American children after arriving in the United States. Jhumpa Lahiri's short story focuses on the process of adaptation of a young Indian woman moving to the United States because of her husband's decision to work abroad. Although the protagonist is a woman, the story is told by a third-person narrator whose point of view coincides with that of an eleven-year-old boy, Eliot, who is looked after every afternoon by Mrs. Sen. Given their relationship of mutual sympathy, Eliot progressively senses Mrs. Sen's state of unease and disorientation due to a condition of constrained displacement. The woman indirectly admits her disapproval of her husband's decision to leave India through comments such as "Here, in this place where Mr. Sen has brought me, I cannot sometimes sleep in so much silence." (Lahiri 1999, p. 115). Through Eliot's eyes and his acute sensitivity, we are provided with a clear picture of the Indian woman's psychological life, dominated by feelings of stasis and entrapment. Indeed, although women's deterritorialization might lead to a questioning of home as a site of patriarchal oppression, in the diaspora, many women are faced with the double burden of preserving the family's national identity while adapting to the new life. Commenting on the painful duality of the female diasporic experience, (Clifford 1994, p. 314) has underlined that women often gain relative independence and control through employment, but they also have to struggle with the insecurities of exile, the demands of family, and the claims of patriarchy. The result is an existence trapped between past and present, in a state of physical and mental isolation. Ruth Maxey, when talking about South Asian American fiction such as Lahiri's The Interpreter of Maladies, points out that U.S. writers representing domesticity-as-female "are interested in anatomising the collision between ... women and the outside world" (Maxey 2012, p. 58). Indeed, several critics have focused on Mrs. Sen's lack of mobility as a result of her obstinate recreation of India in the American context. Chakraborty, for instance, defines her as the victimized and pitiable exemplar of the immigrant woman who cannot cope with humiliation and exclusion in the foreign land (Chakraborty 2008, p. 236). Brada-Williams also argues that the lack of community and participation in the lives of others is the main cause of her homesickness (Brada-Williams 2004, p. 459). Bidisha Banerjee, in her essay No Nation Woman: The Diasporic Woman's Quest for Home (Banerjee 2007), has pointed out that Mrs. Sen tries to attach herself to the collective meaning of being Indian through food and Indian artifacts, which become fetishes evoking memories of female community and kinship. The same idea is shared by Williams (2007), who notes how Mrs. Sen uses food to engender agency and memory as she has no real community to speak of. However, Mrs. Sen's alienation is not only due to her yearning for the authentic home, but also by the progressive recognition of the inauthenticity of all homes. As a result, the cultural baggage-both spiritual and material—she carried over to the new land actually impedes her from fully belonging both to her past and her present home.

One of the most eloquent examples of Mrs. Sen's inability to negotiate a sense of belonging between home as a place of origin and home as the experience of locality in a foreign country is the confused use she makes of the word "home," reflecting its ambivalent meaning in her mind. Eliot notices "that when Mrs. Sen said home, she meant India, not the apartment where she sat chopping vegetables" (Lahiri 1999, p. 116). The ambiguity of the concept of home is not only related to the liminal position occupied by the protagonist, but also to the material as well as symbolic value home 
has in the story, where the physical world merges with the metaphysical aspect of things. A concrete manifestation of the home she has left in India is a cassette recording of all her relatives' voices.

"[S]he played a cassette of people talking in her language—a farewell present, she told Eliot, that her family had made for her. As the succession of voices laughed and said their bit, Mrs. Sen identified each speaker .... The final voice on the tape belonged to Mrs. Sen's mother. It was quieter and sounded more serious than the others. There was a pause between each sentence, and during this pause Mrs. Sen translated for Eliot: 'The price of goat rose two rupees. The mangoes at the market are not very sweet. College Street is flooded.' She turned off the tape. 'These are things that happened the day I left India.' The next day she played the same cassette all over again." (Lahiri 1999, p. 128)

By continuing to listen to those voices and hear the same stories, Mrs. Sen positions her own existence in the past, as if it were frozen in time, stuck in the moments and contexts in which those events were produced. The deep feeling of nostalgia for the people and life she has left in India is temporarily alleviated by the letters she occasionally receives from her family. Eliot learns that "[t]wo things ... made Mrs. Sen happy. One was the arrival of a letter from her family" (ibid., p. 121); the other thing "was fish from the seaside" (ibid., p. 123). Her two sources of happiness derive from an ideological contact with her motherland and mother culture. However, while life in India goes on, she feels excluded from the natural cycle of time. This happens, for example, when she receives a letter announcing the birth of her niece: "My sister has had a baby girl. By the time I see her, depending if Mr. Sen gets his tenure, she will be three years old. Her own aunt will be a stranger. If we sit side by side on a train she will not know my face." (ibid., p. 122). Another letter informs her of her grandfather's death, causing an emotional breakdown in Mrs. Sen not only because of the sad news, but also because she feels totally excluded from all life cycle events.

The same detachment from real life is visible in Mrs. Sen's new home in the U.S., namely in the way she has arranged the furniture. When Eliot enters the apartment for the first time, he notices that the pieces of furniture are all covered: "White drum-shaped lampshades flanking the sofa were still wrapped in the manufacturer's plastic. The TV and the telephone were covered by pieces of yellow fabric with scalloped edges" (ibid., p. 112). Such absence of contact between her-the main inhabitant of the house spending the whole day there-and what should be a familiar place denotes a sterile relationship, lacking in emotional involvement of any kind. No intimate bond has developed between the woman and her house, as if she had not settled down permanently.

Mrs. Sen's failure to inhabit the present and her present space engenders a series of acts of remembrance connecting her to her past, when she had a defined identity and a clear position in the world. She, therefore, enacts a material recreation of her original culture through a series of "diasporic things" representing a tangible bond with the motherland as well as a comforting presence in the new house. A case in point is a blade she had brought from India, "where apparently there was at least one in every household" (ibid., p. 115). It represents a very strong cultural element and Eliot immediately notices the relevance it has in Mrs. Sen's life. She uses it in her daily ritual of cutting vegetables into pieces on the living room floor when she transforms herself into a confident woman mastering perfectly the art of handling the Indian cooking tool.

Facing the sharp edge without ever touching it, she took whole vegetables between her hands and hacked them apart: cauliflower, cabbage, butternut squash. She split things in half, then quarters, speedily producing florets, cubes, slices, and shreds. She could peel a potato in seconds.... While she worked she kept an eye on the television and an eye on Eliot, but she never seemed to keep an eye on the blade. (ibid., p. 114)

In Mrs. Sen's memories, the Indian blade is associated with the moments of joy and sharing she lived in India, surrounded by the chatter of her family and the neighborhood women while cooking vegetables. 
"Whenever there is a wedding in the family," she told Eliot one day, "or a large celebration of any kind, my mother sends out word in the evening for all the neighborhood women to bring blades just like this one, and then they sit in an enormous circle on the roof of our building, laughing and gossiping and slicing fifty kilos of vegetables through the night." (ibid., p. 115)

This image of community life sharply contrasts with the loneliness in which Mrs. Sen performs the ritual in her new home in America. However, the feelings of incompatibility, nostalgia, sense of loss, and disruption intensify her endeavor to belong, to make a house home.

In this respect, India is also recreated through the clothes she wears. Indeed, Mrs. Sen's habit of wearing saris even in the western context, despite the very different weather conditions compared to India, suggests she keeps identifying herself with her native culture, which she is not willing to give up. Her colorful saris are her distinctive trait as Eliot acknowledges the day he first met her: "She wore a shimmering white sari patterned with orange paisleys, more suitable for an evening affair than for that quiet, faintly drizzling August afternoon" (ibid., p. 112). The idea of change represented by Mrs. Sen's saris-"a different pattern each day" (ibid., p. 119)—clashes with the feeling of stasis dominating her life. In an afternoon spent walking along the ocean, for instance, "Mrs. Sen pointed to the water, and said that at a certain moment, each wave resembled a sari drying on a clothesline. 'Impossible!' she shouted eventually, laughing as she turned back, her eyes teary. 'I cannot move.'” (ibid., pp. 129-30). As this last quotation suggests, the paralysis experienced by the woman protagonist is physical as much as psychical. A reason for that is her inability to drive and, consequently, to leave her home. Driving becomes a real obsession for her, not only because it represents the possibility of leading an independent life, but also because it gives her hope of moving back to India. She confesses her wish to Eliot: "'Mr. Sen says that once I receive my driving license, everything will improve. What do you think, Eliot? Will things improve?' 'You could go to places', Eliot suggested. 'You could go anywhere'. 'Could I drive all the way to Calcutta? How long would it take, Eliot?'” (ibid., p. 119). India—which is the place Mrs. Sen perceives as her real home-has a powerful centripetal force, condemning her to a suspended life between a tradition she has already left and the way of life that stubbornly denies her right of entry. On the one hand, as Bhatia claims, memory allows migrant communities "to refashion a space that becomes a meaningful site for empowering those facing marginalization" (Bhatia 1998, p. 512). On the other hand, however, it can become destructive as it may entrap identity.

Mrs. Sen's longing for her homeland is not only expressed in memory, but also in imagination. Moments of the past are frequently fictionalized and the homeland ends up being, using Brah's expression, a "mythic place of desire" (Brah 2005, p. 209), the best of all possible worlds. This tendency emerges, for instance, from Mrs. Sen's hyperbolic description of an anecdote from her past Indian life: "'At home ... [n]ot everybody has a telephone. But just raise your voice a bit, or express grief or joy of any kind, and one whole neighborhood and half of another has come to share the news, to help with arrangements.'" (Lahiri 1999, p. 116). As Salman Rushdie claims in his collection of essays Imaginary Homelands, the creation of an imaginary birthplace is a condition for expatriates, exiles, or emigrants who, in order to cure the painful identity fragmentation of the present, experience a selective appropriation of their cultural memories (Rushdie 1991, p. 10). He also talks about "Indias of the mind" (ibid.) referring to the diasporic subject's unconscious recreation of his or her natal place. In this regard, he points out that "if we do look back, we must also do so in the knowledge ... that our physical alienation from India almost inevitably means that we will not be capable of reclaiming precisely the thing that was lost; that we will, in short, create fictions, not actual cities or villages, but invisible ones, imaginary homelands, Indias of the mind" (ibid.). Mrs. Sen's imagination, however, is neither productive, nor is it a propellant forward. On the contrary, it is projected into the past and prevents her from going on with her present life.

The private museum of memories she has recreated within her American apartment shows her inability to balance remembrance and forgetting. In this regard, Bhabha writes: "it is through this syntax of forgetting — or being obliged to forget - that the problematic identification of a national 
people becomes visible" (Bhabha 1994, p. 310). As the passages from the short story examined reveal, Mrs. Sen tries to recreate her first home, India, by resurrecting idealized memories and transposing elements of a past life into America, thereby transforming both her present and her past home into a chimera.

If for Mrs. Sen, home represents an inward force binding her to the past, for Akhila, the woman protagonist of Ladies' Coupé, exactly the opposite is true. Despite saving her from anomie, with the fate of most unmarried Indian women, her family home has become a prison, both literally and symbolically, from which she is determined to escape. The transitional space of the train coupé, therefore, acquires a transformational force, which makes the leaving of home an opportunity for a new identity formation, as will be discussed in the next section.

\subsection{The Train Compartment in Ladies' Coupé}

Given the story's setting in a train compartment for women, Nair's novel represents the opening up of a space, both literal and figural, within a patriarchal system. Umber Kahiri, in his article “Don't marry, be happy" posted on 26 May 2002 on the Daily Telegraph online, defines Ladies' Coupé as "one of the most important feminist novels to come out of South Asia" since it foregrounds the story of six Indian women of different ages and social classes who question the deep meaning of their feminine identity in contemporary India.

The events take place over one night, when the six passengers, strangers to one another, share a coupé reserved for women only. Each woman tells her own story freely as they know they will not see each other ever again. The protagonist realizes that "she could tell these women whatever she chose to. Her secrets, desires, and fears. In turn, she could ask them whatever she wanted" (Nair 2001, p. 21). The central character, Akhila, is a 45-year-old clerk at the Bangalore income-tax office who has devoted her whole life to her family after her father's premature death. In order to look after her mother and younger brothers and sister, she has put aside her own happiness, but as time passes she starts feeling the need to recuperate her true self as a woman. She leads an ordinary life with military precision, as her sari "heavy with starch" (ibid., p. 82) perfectly represents: "It was perhaps in those years that the starch entered Akhila's soul. Imbuing her every action and word with a delicate film of stiffness that soon became her natural way to talk and be" (ibid.). When the starch which holds her self together becomes so heavy that it prevents her from moving, she decides to do what nobody would expect of a respectable Indian woman: leaving alone on a train journey. Unlike the literary fiction by women writers published in the 1970s and 1980s which, as George has also argued, did not provide much contribution to women's struggle, this kind of narrative tackles feminine desire and creativity from an entirely different angle. Desai, Deshpande, and Saghal's fiction, for instance, usually depict upper-class women who leave their homes after a domestic crisis (caused less by rebellion than boredom) but finally return without changing much of their lives. After analyzing their works, George states that "[t]he failure of these expeditions in search of the self present us with a situation in which we have to acknowledge the limited usefulness of literary texts as political tools for social transformation" (1999, p. 38). Nair's novel, on the contrary, reworks significantly this dynamic by focusing on what Verma and Jatav have defined an "emotional journey" towards self-realization (Verma and Jatav 2014). Akhila is self-consciously transgressive as she chooses to relocate herself. In a 1989 essay titled Choosing the Margin as a Space of Radical Openness, bell hooks suggests that political struggle "can be experienced ... [when] one transgresses, moves 'out of one's place'.... Moving, we confront the reality of choice and location" (Hooks 1989, p. 15). Akhila's reterritorialization via narration and community with other women - which critics such as Bausman (2014) and Dutta (2013) have recently examined—cannot be fully understood unless we consider home as a backdrop providing occasions for resistance and escape in varied ways. In Deterritorializations: The Rewriting of Home and Exile in Western Feminist Discourse, Caren Kaplan writes "we must leave home, as it were, since our homes are often the sites of racism, sexism, and other damaging social practices. Where we come to locate ourselves in terms of our specific histories and differences must be a place with room for what can be salvaged from the past 
and what can be made new" (Kaplan 1987, pp. 194-95). The "private open space" (George 1999, p. 29) of the coupé provides the women passengers with the perfect conditions to reach the compromise between past and future envisaged by Kaplan as well as develop their imagined self.

The novel opens with the idea of liberation offered by the train journey: "This is the way it has always been: the smell of railway platform at night fills Akhila with a sense of escape" (1). For a while, all her responsibilities as a caring woman are suspended and she would be the one who is taken care of. Boarding the train also represents an opportunity for Akhila to feel part of something bigger than the domestic sphere: "[She] has always dreamt of this. Of being part of such a wave that pours into compartments and settles on seats, stowing baggage and clutching tickets. Of sitting with her back to her world, with her eyes looking ahead .... Of a train that trundles, truckles and troops into a station" (1). Akhila's journey is, therefore, not only a form of escape, as it also provides the ideal conditions for constructing a new identity through narrative and memory. Talking about the train journey, Michel de Certeau points out that "[it] is necessary for the birth ... of unknown landscapes and strange fables of our private stories" (De Certeau 1984, p. 88) because "from a train car one can see what one is separated from" (ibid., p. 114). As Chanda comments on the transformation potential of segregated spaces, the compartment becomes a transformative "womenspace" (Chanda 2008, p. 309) as well as a place of retreat and community. While reflecting on her fellow travelers' stories, Akhila thinks: "They could be her .... She could be them. Each confronting life and trying to make some sense of its uncertain lines" (Nair 2001, p. 97). When asking the other women questions, Akhila is surprised at her own eloquence: "this evening, she had behaved so unlike herself. Eager to spill her secrets. Anxious to probe into lives. Willing to talk" (ibid., p. 65). As a catalyst of the women's "talking cure," that hybrid and transitional place is ideal to raise questions about what it actually means to be at home. The idea that emerges from the passengers' stories is that, paradoxically, one's "real home" is the very space in which women feel alienated, estranged and unsettled. In this respect, Ahmed has observed that sometimes the most comforting and comfortable place is the in-between, not because one has nearly arrived, but because "one has the security of a destination" (Ahmed 1999, p. 330). Metaphorically speaking, the women protagonists are following an itinerary of their own choice, which is not dictated by external authorities, but by the confidences and conversations they exchange in the intimate space of the coupé.

Breaking the silence of their private spheres, the women exchange their experiences, question their homes, and share strategies of identity survival. Foucault highlights the great strength of discourse, which transmits and produces power, but also "undermines it, exposes it, renders it fragile and makes it possible to thwart it" (Foucault 1978, p. 101). Moreover, the women's detached position allows a full understanding of the self and what they have left behind. According to Carole Boyce Davies, "[h]ome can only have a meaning once one experiences a level of displacement from it" (Boyce Davies 1994, p. 84). Not only is reality depicted in the women's narrations, but their very movement across borders-both physically and figuratively-expands their vision and develops their ability to see more. Home, therefore, becomes a place the leaving of which is a source of speech, reflection, and understanding. Such a "poetics of dislocation," as (Friedman 2004, p. 207) defines it, giving voice to those who are silenced by society, represents a means of re-claiming territory and recuperating a female selfhood. On the therapeutic effect of narration, Akhila reflects:

All these women ... are trying to make some sense of their own lives by talking about them. And I thought I was the one trying to define the reality of my life. They need to justify their failures as much as I do. And by preying on the fabric of each other's lives, and seeking in it a similar thread that in some way will connect our lives, we are trying to feel less guilty for who we are and what we have become. (Nair 2001, pp. 144-45)

Interestingly, the passengers' stories of dislocation help the protagonist to relocate: they give a shape, a contour, a meaning to the past itself. Memory, therefore, becomes a collective act which leads to the creation of a community of strangers linked by a common bond: the symbolic lack of a home. 
The passengers' stories show that they have all experienced the feeling of being "homeless at home" (Dickinson 1960, p. 653), alienated in a place which they perceive as unfamiliar and even threatening. The experiences they tell form a single overarching story of women's search for independence, but also of homesickness, that is, sickness of (and not for) home. The most natural means the women travelers find to overcome their feeling of displacement is to recollect their past and tell their personal stories. Paul Asbury Seaman, in his contribution Rediscovering a Sense of Place, argues that "to connect more fully with the present-to feel at home-[one has] to reconnect with [one's] past" (Seaman 1996, p. 38). The storytelling, thus, becomes a methodology to address narrations of reality, but also to promote a process of inventing new spaces while challenging existing realities. The setting of the storytelling is the "dead time" of railway travel, which traditionally functions as background to the main events, but in Ladies' Coupé is generative and recuperative. By putting together fragments of memory, the six women are making an attempt to shape a new identity. In this respect, Salman Rushdie's metaphor of the "broken mirrors" is quite pertinent as he claims that the "pieces" of memory have an incredibly creative power as "they [are] remains: fragmentation made trivial things seem like symbols [with] numinous qualities" (Rushdie 1991, p. 12). New knowledge and new ways of seeing can be constructed out of the myriad of combinations of memory "scraps" emerging from the past. Consequently, figuring out the real meaning of self is an interactive process between imagination and memory.

As a result, memory is not only reflexive, but also productive, as the recuperation of the past leads to the projection of a future self. The women protagonists' journey of self-discovery becomes an exploration of their most intimate desires. The central woman character, more than all the others, is looking for a way to express these intimate desires freely for the first time in her life. She remembers her mother's mantra: "Women never offered their bodies to men before their union was sanctified by marriage. Women never went away with men who were not their husbands. Women never knew what it was to desire" (Nair 2001, p. 160). During the train journey, Akhila subverts this oppressive thought into an ability to look at the future and give voice to her most intimate secrets. A case in point is represented by the erotic dream she has during the night, protected by the intimacy of the berth. She dreams of a man who can see the woman she has hidden for a long time: "You are Akhila', he says and comes to stand by her. 'You are Akhila the woman. Everyone else might have forgotten about the woman within you. But I see her. I see the desire in her eyes, the colours in her heart.'" (ibid., p. 98). That scene represents Akhila's need to feel simply like a woman and free herself from the constraints imposed by society as someone's daughter, sister, aunt, sister-in-law, provider, employee. This desire to openly express her own femininity materializes as soon as she reaches her destination, arriving at the seaside town of Kanyakumari. There, Akhila seduces a boy, ignoring any judgment the people around her might pass. Evidently, the train journey was the catalyst for this process of self-discovery and the coupé proved to be the creative space in which she was able to review her past, question her present and conceive a different future.

The very final scene of the book shows Akhila looking at her return ticket, determined to "wrest the reins of her life back" (ibid., p. 290). Hence, home is both the starting point and point of arrival of her journey, but with two completely different meanings: at the beginning, it embodies the nest/prison duality, while at the end, it becomes the site for experimenting a new way of being a woman. As Akhila reflects, "within me is a woman I have discovered" (ibid., p. 284) and "[s]he has no more doubts about what her life will be like if she lives alone" (ibid., p. 285). Interestingly, in a story about travel, such as Ladies' Coupé, home-and the life of women within the home-is the central force that triggers their reflections and consequent reactions. For Akhila, home takes shape on the move, thereby becoming the place to which the self is going, not a paralyzing remembrance. Rather than a fixed entity, home is, therefore, a projection of her own imagination and desire. Her idea of it is future-oriented and not weakened by nostalgia of the past. Instead, it is empowered by the possibility of creating counter-narratives to the present world. Moreover, Akhila, like her fellow women passengers, has chosen the household as the primary battlefield upon which to negotiate a new identity and subvert the traditional idea of women being a part of the home. The change they envisage is not a revolutionary 
disruption of old norms, but resistance from within a male space through a smooth transition. As one of the travelers observes, they should look for "the middle path, the golden mean" (ibid., p. 199); that is, a compromise to cope with patriarchy. Indeed, the coupé is just a temporary "breathing space" for the women, allowing only momentary alliances. By its very nature, it is open and yet closed. Its liberating potential is counterbalanced by a condition of restriction, the sense of escape is neutralized by that of enclosure. Hence, what Nair is suggesting is that home-conceived beyond its physical confinement-may, in fact, be the place where the oppositional forces represented by the coupé can adjust and stabilize.

\section{Conclusions}

Home is an arena in which massive identity negotiations between often competing ideological pressures take place. As the analysis of the two works of fiction examined in this article has shown, the symbolic importance of home engenders struggles for self-redefinition beyond its physical confines. The women protagonists' domestic wars acquire a greater significance in the hybrid contexts of the diasporic land and the train compartment because of their blurred boundaries. Indeed, their undefined limits make them "homeworlds," to use Helff's expression (Helff 2013, p. 3); that is, permeable spaces in which public and private merge. There, the women's individual fears, uncertainties and unease transcend the limits of the household and acquire a wider social connotation. On the one hand, Mrs. Sen represents the risk for migrant women of being further marginalized in the diasporic space. Despite the geographical shift, they still consider their home as the microcosm of the Indian social structure, thus failing to come to terms with the past and embrace a new life. The material dimension of Indianness is reproduced within the house, which, behind its appearance as a safe haven protecting women from an unknown world, conceals the features of an emotional and physical prison. Hence, the cultural belongings Mrs. Sen carried over from India do not facilitate belonging in the new land. On the contrary, they impede it, not so much because they do not adequately reproduce an authentic home as because they reveal the inauthenticity of all homes, both past and present. On the other hand, Akhila occupies what Avtar Brah calls the "diaspora space" (as opposed to the diasporic space), i.e., "the point at which boundaries of inclusion and exclusion, of belonging and otherness, of 'us' and 'them', are contested" (Brah 2005, p. 226). The dialectical conversations and exchanges between the women passengers make it a site for contestation in which "the native is as much a diasporian as the diasporian is the native" (ibid., italics in original). Unlike Mrs. Sen's displacement, which arouses a desire for the homeland, Akhila's dislocation allows the questioning of borders and the growth of a "homing desire" (ibid., p. 32) based on a constructive ideal and not on an ideology of return. In her case, deterritorialization leads to a thorough examination of her female selfhood which does not translate into a purely aesthetic pursuit, but a transgressive (even political) act. Consequently, the leaving of home-and the memories and narrations associated with it-is represented as a significant opportunity for power negotiations. In both cases, however, it may be claimed that the homes lived by the women protagonists are unreal to the extent that they are not to be considered in their physicality, but as metonymies of the Indian women's individual and social identity. As Helff has pointed out in her book Unreliable Truths. Transcultural Homeworlds in Indian Women's Fiction of Diaspora, in modern narrative patterns of Indian literature, the relationship between the intertextual and intratextual world is very deep and "the imaginary world is irrefutably an inherent part of the social world" (2013, p. 16). Consequently, the individual homeworlds narrate stories of a globalized reality.

In conclusion, home, either from the perspective of a diasporic land or that of a train coupé, is a gendered and generated space reflecting the habitus of its creator as well as the political, material, and psychical conditions its female dwellers experience within it. Women's way of conceiving their homes challenges the phenomenology of the domestic sphere and becomes increasingly linked with the notion of movement. Being much more an interior place than a material entity, home travels with the subject who travels and, consequently, women's individual re-learning process can be carried out 
on the move, when ever-changing perspectives are enabled, new ways of seeing reality are discovered, and multiple possibilities of identity construction are opened up.

Funding: This research received no external funding.

Acknowledgments: I wish to thank Professor Christopher John Garwood who generously helped me with the linguistic revision of the manuscript. I also thank guest editors Eleonora Rao and Robert Tally for their interest in my topic.

Conflicts of Interest: The author declares no conflict of interest.

\section{References}

Ahmed, Sara. 1999. Home and Away: Narratives of Migration and Estrangement. International Journal of Cultural Studies 2: 329-47. [CrossRef]

Armbruster, Heidi. 2002. Homes in Crisis: Syrian Orthodox Christians in Turkey and Germany. In New Approaches to Migration? Transnational Communities and the Transformation of Home. Edited by Al-Ali Nadje and Koser Khalid. London: Routledge, pp. 17-33.

Banerjee, Bidisha. 2007. No Nation Woman: The Diasporic Woman's Quest for Home. In Interpreting Homes in South Asian Literature. Edited by Malashri Lal and Sukrita Paul Kumar. New Delhi: Doring Kindersley, pp. $168-80$.

Bausman, Cassandra. 2014. "Into a Horizon I will not Recognize." Female Identity and Transitional Space Aboard Nair's Ladies Coupé. Iowa Journal of Cultural Studies 15: 56-79. [CrossRef]

Benjamin, David N. 1995. The Home: Interpretations, Meanings and Environment. Aldershot: Avebury.

Bhabha, Homi. 1992. The World and the Home. Third World and Post-Colonial Issues 31/32: 141-53. [CrossRef]

Bhabha, Homi. 1994. The Location of Culture. New York: Routledge.

Bhatia, Nandi. 1998. Women, Homelands, and the Indian Diaspora. The Centennial Review 42: 511-26.

Boyce Davies, Carole. 1994. Black Women, Writing and Identity: Migrations of the Subject. London: Routledge.

Brada-Williams, Noelle. 2004. Reading Jhumpa Lahiri's Interpreter of Maladies as a Short Story Cycle. Melus 29: 451-64. [CrossRef]

Brah, Avtar. 2005. Cartographies of Diaspora: Contesting Identities. New York: Routledge.

Brown, Bill. 2001. Thing Theory. Critical Inquiry 28: 1-22. [CrossRef]

De Certeau, Michel. 1984. The Practice of Everyday Life. Berkley and Los Angeles: University of California Press.

Chakraborty, Paulomi. 2008. Refugee Women, Immigrant Women: Partition as Universal Dislocation in Jhumpa Lahiri's Interpreter of Maladies. In Partitioned Lives: Narratives of Home, Displacement and Resettlement. Edited by Anjali Gera Roy and Nandi Bhatia. New Delhi: Doring Kindersley, pp. 227-39.

Chanda, Geetanjali Singh. 2008. Indian Women in the House of Fiction. New Delhi: Zubaan.

Clifford, James. 1992. Traveling Cultures. In Cultural Studies. Edited by Lawrence Grossberg, Cary Nelson and Paula Treichler. New York: Routledge, pp. 96-116.

Clifford, James. 1994. Diasporas. Cultural Anthropology 9: 302-38. [CrossRef]

Dasgupta, Sanjukta. 2007. Locating "Home" in a Liminal Space: Longing and Belonging in the Fiction of "Bengali" American Women Writers. In Interpreting Homes in South Asian Literature. Edited by Malashri Lal and Sukrita Paul Kumar. New Delhi: Doring Kindersley, pp. 75-96.

Dickinson, Emily. 1960. \#1573. In The Complete Poems of Emily Dickinson. Edited by Thomas H. Johnson. Boston: Little, Brown and Co., pp. 652-53.

Dutta, Nandana. 2013. Indian English Women's Fiction and the Fascination of the Everyday. In Writing India Anew. Indian English Fiction 2000-2010. Edited by Kirshna Sen and Rituparna Roy. Amsterdam: Amsterdam University Press, pp. 145-59.

Foucault, Michel. 1978. The History of Sexuality. New York: Pantheon Books.

Foucault, Michel. 1986. Of Other Spaces. Diacritics 16: 22-27. [CrossRef]

Friedman, Susan Stanford. 2004. Bodies on the Move: A Poetics of Home and Diaspora. Tulsa Studies in Women's Literature 23: 189-212. [CrossRef]

George, Rosemary Marangoly. 1999. The Politics of Home. Postcolonial Relocations and Twentieth-Century Fiction. Berkley and Los Angeles: University of California Press.

Helff, Sissy. 2013. Unreliable Truths. Transcultural Homeworlds in Indian Women's Fiction of Diaspora. New York: Rodopi. 
Hooks, Bell. 1989. Choosing the Margin as a Space of Radical Openness. Framework 36: 15-24.

Hooks, Bell. 1991. Yearning: Race, Gender, and Cultural Politics. London: Turnaround.

Kaplan, Caren. 1987. Deterritorializations: The Rewriting of Home and Exile in Western Feminist Discourse. Cultural Critique 6: 187-98. [CrossRef]

Lahiri, Jhumpa. 1999. Mrs. Sen. In Interpreter of Maladies. London: Flamingo, pp. 111-35.

Lal, Malashri, and Sukrita Paul Kumar. 2007. Introduction. In Interpreting Homes in South Asian Literature. Edited by Malashri Lal and Sukrita Paul Kumar. New Delhi: Doring Kindersley.

Lau, Lisa. 2006. Emotional and Domestic Territories: The Positionality of Women as Reflected in the Landscape of the Home in Contemporary South Asian Women's Writings. Modern Asian Studies 40: 1097-116. [CrossRef]

Maxey, Ruth. 2012. South Asian Atlantic Literature, 1970-2010. Edinburgh: Edinburgh University Press.

Miles, Malcolm. 2000. After the Public Real: Spaces of Representation, Transition and Plurality. Journal of Art and Design Education 19: 253-61. [CrossRef]

Mohanty, Chandra Talpade, and Biddy Martin. 1986. Feminist Politics: What's Home Got to Do With It? In Feminist Studies/Critical Studies. Edited by Teresa de Lauretis. Bloomington: Indiana University Press, pp. 191-212.

Morley, David. 2000. Home Territories: Media, Mobility and Identity. New York: Routledge.

Nair, Anita. 2001. Ladies' Coupé. New York: Penguin.

Pallasmaa, Juhani. 1995. Identity, Intimacy and Domicile. Notes on the Phenomenology of Home. In The Home: Words, Interpretations, Meanings and Environments. Edited by David N. Benjamin. Aldershot: Avebury, pp. 131-47.

Rose, Gillian. 1993. Feminism and Geography: The Limits of Geographical Knowledge. London: Blackwell, Polity.

Rosenstein, Lucy. 2007. Not a Home: Hindi Women Poets Narrating "Home". In Interpreting Homes in South Asian Literature. Edited by Malashri Lal and Sukrita Paul Kumar. New Delhi: Doring Kindersley, pp. 145-58.

Rushdie, Salman. 1991. Imaginary Homelands: Essays and Criticism 1981-1991. London: Granta Books.

Seaman, Paul Asbury. 1996. Rediscovering a Sense of Place. In Strangers at Home: Essays on the Effects of Living Overseas and Coming 'Home' to a Strange Land. Edited by Carolyn D. Smith. New York: Aletheia, pp. 36-56.

Verma, Anjali, and Prerna Jatav. 2014. Psychological Explorations. A Study of Anita Nair's Ladies' Coupé. In Contemporary Women's Writing in India. Edited by Gulati Varun and Mythili Anoop. London: Lexington Book, pp. 123-30.

Williams, Laura Anh. 2007. Foodways and Subjectivity in Jhumpa Lahiri's Interpreter of Maladies. Melus 32: 69-79. [CrossRef] 